\title{
Household Waste Communication Campaign in the Family Planning Village in Medan City
}

\author{
http://dx.doi.org/10.25008/jkiski.v6i1.522 \\ Lusiana Andriani Lubis ${ }^{1}$, Syafruddin Pohan ${ }^{2}$ \\ ${ }^{1,2}$ Faculty of Political dan Social Sciences, Universitas Sumatera Utara \\ J1. Dr. Sofyan No. 1, Medan 20154, North Sumatera - Indonesia \\ *Corresponding author: lusiana@usu.ac.id
}

Submitted: February 20, 2021, Revised: March 25, 2021, Accepted: May 10, 2021

Accredited by Kemristekdikti No. 28/E/KPT/2019

\begin{abstract}
A research phenomenon is a model of communication carried out by district government officials to create public awareness about household waste. The aim of this research is to analyze the model of communication carried out by district government officials to make people aware of how to deal with household waste. This research uses interpretive qualitative method, in which data are selected by purposive sampling. Data collection techniques are Focus Group Discussion and observation. The results of this research show that through face-to-face communication and group communication district government officials, ranging from the head of environment office, family planning cadres and family welfare movement (PKK) activator team, community leaders to village head, had tried to perform their duties properly in making residents in two areas of family planning (KB) village aware about the impact of household waste. Persuasive communication is the model of communication where the source actively seeks to influence the recipient who is in a passive position. Due to differences in perceptions, the process of exchanging messages during the campaign was one-way, namely from the source to the recipient. The model of communication which is developed in the activity is a command system in which district government officials give a command to the residents of the family planning village where the participation of the people especially those who rent houses in the management of household waste is low.
\end{abstract}

Keywords: Communication campaigns; household waste; family planning village; Medan

\section{Introduction}

The problem of waste is inseparable from a residential area. As population grows, of course, the problem of waste will affect the consumption needs of residents that continue to soar. The waste can be in the form of household waste, industrial waste, and even office waste. Until now, tackling the problem of waste remains urgent at every level of government as the mountain of waste at landfills continues to rise. Without the best solution to this problem, it is undeniable that in the next 50 years people will coexist with garbage at their homes because there will no longer be land to dispose of garbage. Therefore, one of many ways to address the problem of waste is campaign communication conducted by local government officials to educate the community to increase their knowledge, awareness, and care about the management of household waste. This way they will be able to overcome the problem of waste at their homes and in the surrounding environment. This is the focus of the attention of researchers, who are 
still related to the research that they have done before. (Lubis and Wijaya, 2017; Lubis and Pohan, 2018; Lubis and Pohan 2019).

The Environment Office of North Sumatra Province recorded the total amount of waste produced by the province with a population of 14.4 million reached 10.1 tons per day, or 3.7 million tons per year. The figures were uploaded by Gatra.com (accessed on January 11, 2020).

The Website of the Ministry of Environment and Hygiene describes the composition of waste produced by the people of North Sumatra as follows:

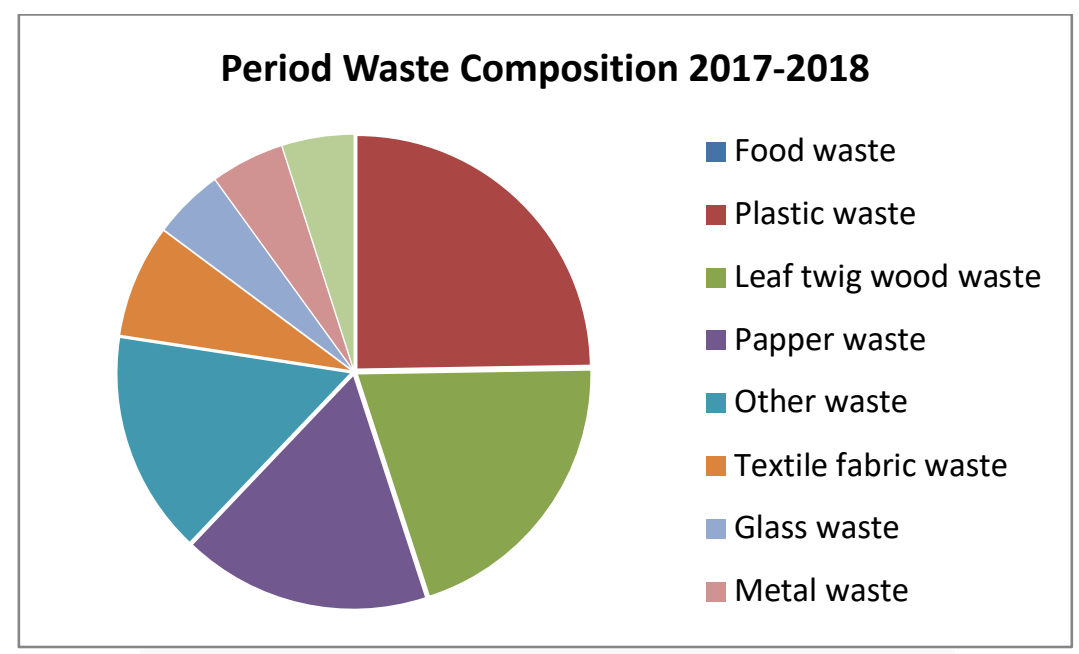

Figure 1. An overview of The Composition of The Waste.

The diagram shows that food waste contributes $38.64 \%$ of the total waste, followed by plastic waste at $15.27 \%$, leaf twig wood waste at $12.39 \%$, paper waste at $10.41 \%$, other waste at $9.34 \%$, textile fabric waste at $4.51 \%$, glass waste at $3.01 \%$, metal waste at $2.69 \%$ and rubber leather waste at $2.65 \%$. The percentage of plastic waste that reaches $15.27 \%$ of the total waste suggests that plastic waste is the second-largest contributor of waste after food waste. The data confirm the statement by the Indonesia Solid Waste Association in 2014 that plastic waste ranks second in terms of waste production, contributing $14 \%$ of 5.4 million tons of total waste production per year.

The research conducted by Astuti and friends (2018), showed that $82.9 \%$ of people who were surveyed know how to sort organic and inorganic waste. The knowledge is then developed into the concept of 3R (Reduce, Reuse, and Recycle). Furthermore, Ekasari (2018) conducted a research on the use of reusable bags by individuals. This research is aimed to promote public awareness and change people's behavior to care about the environment (pro-environmental behavior) by no longer using plastic bags and replacing them with reusable bags. The results of this research showed that this policy is considered less effective because the price is still too cheap.
Moreover, this policy is not continued so that people still use plastic bags, even the retailer does not ask if consumers want to use plastic bags or not.

The research conducted by Marliani (2014) found that utilizing and managing household waste should involve various components of society and pay attention to the characteristics of waste, environmental characteristics, and socio-cultural existence of local communities. The last community service conducted by Lubis, Arif, and friends (2019) in the village of Kampung KB Batang AngkolaTapanuli Selatan Subdistrict, through Information Communication and Education (KIE), provides training to the community to utilize the onset of rice waste/bran rough as a duck egg wrapper that produces salted eggs. The outer salted egg can add to the variety of family intake where the salted egg contains a better nutritional value, more durable and can be sold to increase the cost of school children (snacks, transportation).

From the research and devotion above, researchers realize that it is interesting to continue this research related to household waste (organic and inorganic) so that household waste can be resolved and even can be processed into useful products for household needs. In addition, homes and surrounding 
environment will be clean and healthy. The aim of this research is to analyze the model of communication carried out by district government officials in making people aware of how to deal with household waste produced by families as well as to find a model of campaign communication in overcoming household waste.

\section{Theoretical Framework}

The increasingly unavoidable environmental damage has prompted many environmental activists to actively start campaigning for the management of waste, such as household waste (organic and anorganic), industrial waste, office waste, trade waste, and other. According to official data released in 2017, the ocean contains about 51 trillion microplastic particles, or 500 times more than stars in the galaxy. Plastic waste is found in 300 billion pieces in the Arctic which was previously a pristine and remote island in the Pacific, and on the uninhabited Henderson Island believed to have the highest concentration of plastic pollution in the world (Ananda, 2018).

The report of a travel blogger social media influencer Febrian, who learnt from an article he read shows that Indonesia is one of the largest plastic straw waste-producing countries in the world. Febrian finally decided not to use plastic straws anymore and tried to educate the public on social media to reduce and even abandon the use of plastic straws. Febrian also cooperated with one of stainless steel straw manufacturers whose some of the sales will be donated to the field of conservation in need (Intan, 2018).

Hendra in Juniman (2018) has targeted this movement to reduce the use of plastic straws by up to 100 percent. However, he realized the target will not be achieved in the short run. Also besides, Hendra said his company is looking for ways to replace large straws for float-type drinks and thin straws for warm drinks such as coffee that are still provided in its stores. Hendra said the type of straw will be replaced with the one using environmentally friendly materials. Fatia and Yogi (2019) researched the No Straw Movement. People are educated that plastic or microplastic waste from straws entering the ocean will be eaten by marine animals that are eventually consumed by humans. In addition to inviting citizens, this movement also involves industry players to care about the environmental impact by no longer providing plastic straws. The results of the study have brought about changes to the values, attitudes, and personalities of individuals.

Tania and Sri Rijati (2019) conducted a research in Jatinangor Sub-district which is progressing rapidly in the field of economy. Therefore, Zero Waste or Zero Waste makes every human being evaluate the lifestyle they have adopted and see how something they have consumed can negatively impact the environment. The results of the study yielded three recommendations, (1) optimization of waste management and waste bank functions, (2) educating individuals and communities, especially students and housewives to apply Zero Waste in order to minimize the production of personal and household waste by applying the principles of 5R: Refuse, Reduce, Reuse, Recycle, Rot in daily life.

Furthermore, Cox (2010) revealed that environmental communication is a constitutive and pragmatic means to provide an understanding of the environment to the community. Environmental communication as a means of constitutive means that environmental communication helps in the representation of nature and environmental problems that are also the subject of individual perceptions of nature. By shaping perceptions about nature, environmental communication invites individuals to see the surrounding nature such as forests, rivers, seas, and so on as a threat or it can also be a source of abundant natural wealth, as well as a vital and valued life support system. While pragmatic environmental communication is more educational and helps individuals in solving environmental communication problems. Problem solving and debate are often part of public education campaigns. Environmental communication is not an easy thing to do, it takes a good communication strategy prepared by the communicator (community, local government, or related parties) so that the message on environmental issues is easily received by the communion (audience).

Also besides, Alexander G Flor (2004) in Cangara (2018) argues that environmental communication is the application of approaches, principles, strategies, and communication techniques to protect and manage the environment. This can be interpreted as the exchange of information, 
knowledge, and wisdom between humans and the environment. Flor (2004) says the three main assumptions in environmental communication are exchange or transaction, (1) material, (2) energy, and (3) information, between the environment and other living systems. An absolute environmental communication program should focus on empowering the audience, engaging it, and not putting it in a passive position.

The opinions of Flor (2004) and Cox (2010) are very relevant to elaborate in the realm of environmental communication. This is inseparable from the phenomenon where humans and the environment are two sides of the currency that cannot be released. The approach becomes very complex and must also take into account aspects of cultural perception in the context of cross-cultural communication. Cultural perception is one of the sub-chapters of intercultural communication that must be understood by people of different cultures (Lubis, 2018).

Cultural perception is the process by which we become aware of the many stimuli that affect our senses. Cultural perception affects stimuli (stimulus) or messages that we absorb and meaning that we give to someone/other people from different cultures when they reach consciousness. The important stage of cultural perception is the worldview, social organization, and symbols (verbal and non-verbal). Therefore, the perception has a very broad meaning, concerning the giving of meaning to social objects and events in the environment (Lubis, 2018). Perception is an integrated activity, so that all that are in the individual such as feelings, experiences, thinking abilities, terms of reference, and other aspects that exist in the individual community will play a role (Lubis, and Pohan 2018; Walgito (2000).

Perception will be in line with the communication competence carried out by the communicator to his communicant so that changes in attitudes and behaviors are expected to be felt. A research conducted by Lubis and Pohan (2018) shows that Family Planning (KB) instructors must have communication competence in their field in carrying out fieldwork to achieve the expected goals. Furthermore, Lubis and Pohan (2019) also found that the form of communication conducted by $\mathrm{KB}$ extension officers (PKB) in carrying out Communication, Information and
Education in kampung $\mathrm{KB}$ village in Purba Nauli Batang Angkola, Tapanuli Selatan District, through interpersonal communication with home visits, Group Communication in Posyandu or Village Hall, Mass Communication through the dissemination of brochures and posters has assisted in promoting the awareness and attitude of new fertile age couples to use contraceptives. However, the need for technical guidance is more driven to the $\mathrm{KB}$ Cadres in the village so that the knowledge and skills of PPKBD and KB cadres can be better when providing counselling to the community. Then Lubis and Haris Wijaya (2017) found that the communication strategy conducted by family planning extension officers (PKB) in Langkat by picking up the ball and joining groups in integrated health service post (Posyandu) through KB cadres proves effective to approach new KB acceptors. This serves as a reference for researchers to conduct the study.

Furthermore, Law No. 52 of 2009 on Population Development and Family Development which lays the basis for the implementation of the Population and Family Planning Program suppresses the authority of the National Demography and Family Planning Agency (BKKBN) to not only focus on population control but also pay attention to family development issues. Therefore, to strengthen the KKBPK program in 2015-2019, $\mathrm{BKKBN}$ is expected to develop an activity that can strengthen efforts to achieve targets or targets that are directly in contact and provide benefits to the community, which in miniature is family.

Then Article 7 of Law no.52 of 2009 stipulates there are 8 (eight) family functions, namely religious functions, socio-cultural functions, love functions, protection functions, reproductive functions, socialization and education functions, economic functions, and environmental coaching functions. Wirdhana (2013) explained each function, among them the function of fostering the environment calls for families to give the ability to members of their families in placing themselves in a harmonious situation balanced by following the rules and the carrying capacity of nature and the environment that has changed dynamically all the time. A family is a reflection of how it can apply its suitability to the environment, and contribute to the environment, including small things such as the cleanliness of the 
environment around the house including household waste, tree planting, and others. Therefore, something useful for the development of this environment is done in kampung KB.

\section{Material and Methodology}

The North Sumatra Environment Agency has reported that household waste contributes $38.64 \%$ of the total waste which reaches 10.1 tons per day in the province with a population of 14.4 million (Gatra.com, 2020). North Sumatra province is quite extensive, therefore researchers map the locations for the research based on observations and interviews with environmentalists. Three locations are planned to be research sites, by paying attention to criteria: population density, location, and environment (Bungin, 2015). From these criteria, there are two research locations, Deli Serdang Regency and Medan City. Deli Serdang Regency covers an area of 2241, 68 $\mathrm{km} 2$ with a population of $2,155,625$, which is the largest in North Sumatra. There are 22 subdistricts and 14 subdistricts and 380 villages. Medan consists of 21 sub-districts and 151 subdistricts with an area of $265.00 \mathrm{~km}$ and a population of about 2.478 million with a population density of 9352 inhabitants $/ \mathrm{km} 2$ (Population Data and Statistics for 2017, 2018). In general, the population is made up of diverse ethnic groups, namely Malay, Javanese, Karo, Mandailing, Batak Toba, Minangkabau, Aceh, Chinese, and others. The results of this study represent only one location, namely in the city of Medan.

This research uses a qualitative method through an interpretive qualitative approach. The designation of research locations is based on the criteria of Kampung KB, namely densely populated communities, low economic levels, heterogeneous communities (multiple people), railroad slums for the village of Gaharu East Medan District, and riverbanks for Asam Kumbang village. The population is village government officials and KB cadres in the two villages. The informal number of researches is eight people out of fifteen invited people and the activity takes place through the Grop Focus Discussion. The activity was carried out in Asam Kumbang village by complying with health protocols in the midst of the Covid 19 pandemic, namely from July 2020 to August 2020.
The eight informants are key figures consisting of the head of the environment office, the Community Resilience Institute, the PKK mobilization team, and the KB Cadres. Triangulation to four figures, namely environmental activists, village head of Asam Kumbang, and community leaders. The total number of informants is eleven. Although the number is limited, the data was collected by deepening data to the informants. Furthermore, the strengthening of the data was done through direct observation of the $\mathrm{KB}$ village area by researchers. This is as said by Mulyana (2018) and Kriyantono (2010) that the qualitative approach emphasizes more on the issue of interview depth (quality) of data rather than quantity. Analysis of data according to the views of Miles and Huberman (2009), by stages; create categories/themes, display data, then the data is earned in the form of synopsis to facilitate the exposure and affirmation of conclusions (conclusion drawing and verification).

\section{Result and Discussion}

Field research took place from July 2020 to August 2020. Research in the field was delayed several months due to the COVID-19 pandemic and Large-scale Social Restrictions (LSSR) in the period of (March-early May 2020). In addition, several lecturers and employees died due to COVID-19 and University of North Sumatra (USU) again imposed a lockdown policy, making it difficult for researchers and teams to set date to go down to the field. Focus Group Discussion (FGD) was participated by eleven out of fifteen people invited from two different locations, but still in Medan. The FGD took place on July 6 2020, at Asam Kumbang Subdistrict Medan Selayang.

FGD participants represent the government officials of Asam Kumbang Village and Gaharu Village consisting of ward heads, KB cadres, PKK cadres, Babinsa (village supervisory non-commissioned officer), PKK, and community leaders. This is sufficient for the research team to comply with the COVID-19 protocols. Even the research team prepared the FGD room by following per under the Covid 19 protocol standards, from the seating arrangement of participants, mandatory masks, hand sanitizer, and hand soap. The activity lasted for approximately two hours, and all participants actively asked questions 
(Absence, orderly events, and photo documentation attached in the research report).

The FGD questions are about: Communication, information, and education about organic and non-organic waste, community knowledge level, community awareness and behavior, penalties or sanctions for people who dispose of waste carelessly, and efforts to utilize waste for a productive business.

The formulation of minutes on the process of FGD activities is as follows:

\begin{abstract}
Mrs. R. Said that; "initially the community dumped waste into the vacant land until finally they were given advice not to throw garbage in the place. However, residents (especially those who rent a house) do not heed it, but still, throw garbage in the empty land. Finally, Mrs. R. gave a lure to them, if anyone wants to separate the garbage between wet and non-organic waste such as plastic and detergent wrap that cannot be destroyed at least $1 \mathrm{~kg}$, they will get 1 point, and the points will be exchanged for groceries. According to him, so far there have been 25 people who have collected the waste, but they have difficulties marketing products such as tissues, wallets, and carry-on bags. She delivers her message directly through the form of face-to-face communication, and also through new forms of media communication such as social media, namely WhatsApp Group."
\end{abstract}

Mrs. M, as head of environment four Asam Kumbang village. The question is about socialization about household waste.

"She replied that socialization is done from house to house when I cross the homes of residents who have people. But what makes me difficult is the residents who rent house monthly and every time the residents change besides those who do not report directly, it will usually be late for re-socialization. There is tendency not to care about the garbage at their house and even let the garbage accumulate in front of their house. When you want to scratch, the guysno longer rent the house. This makes it difficult to take action".

Mr. S. Head of environment six Asam Kumbang village. Questions about socialization and handling of waste in the work area environment.

He said: "I visited from one house to another to socialize the impact of this waste on the family and the environment. Moreover, nowadays it often rains heavily, and floods occur everywhere. However, residents continue to dispose of garbage carelessly moreover in empty land, They have been repeatedly given advice, but still the advice goes unheeded".

Mr. J. Territorial staff of the Army. Question: His role in the community, especially waste damages the environment.

He said: "Regarding garbage disposal fees, residents have been obliged to pay garbage and security dues at Rp. 15,000 (fifteen thousand rupiah) a month. But some of them do not pay for it even though they have obtained security facilities. The garbage itself will not be quoted and told to dispose of itself to the garbage disposal. Even so, I noticed that he always left a mess in front of his house. Decisive action has been taken, but it is still erratic and I still hope he will be aware of it. Communication is delivered directly and face-to-face to the residents. Some of them are aware of obligation to pay garbage disposal fee and there is also an emphasis for the errant. The reaction is willing to pay by force, but some do not want to pay".

Mrs. K. Family Planning's Cadre at Kampung KB Gaharu. Question: Communication conducted in the delivery of waste handling in the village KB location.

She said: "Communication was delivered directly and face-to-face. When I passed by the people's house I saw the garbage piling up and having not been disposed of. I explain the dangers of waste to the health of persons and families, especially toddlers. How to separate organic and non-organic waste. It is difficult to promote the awareness of the public especially those living near the railway tracks. It is difficult to cooperate with them. On average they rent houses and have precarious jobs. I still work independently to handle waste and set an example to the community so that they 
will care about and contribute to handling it. For the citation of garbage dues, it is done but it seems that many residents were not willing to pay it. The garbage is not removed and becomes a problem to the eyes and the surrounding environment".

Mrs Y, as Head of environment of Gaharu. Question: Sanctions given to citizens who do not want to care about their household waste?

She said: "If I see directly a resident
throwing garbage carelessly, then I will
come to his house. I'll insinuate subtly,
like "Buk, Excuse me there's a package".
I also found residents who are aware
and ashamed. Furthermore, she also
hoped for decisive action and
cooperation of all government officials,
ranging from those of the environment
office, villages to sub-districts in terms
of sanctions given to citizens that are
difficult to receive advice. Moreover, at
the moment the rainfall is quite high and
flooding occurs everywhere, we bother
to be the head of the environment".

Mr. S, Community Leaders. Question: As a community leader who cares about the environment, what do you done in realizing the community about his behavior towards family waste.

He said: "The issue of waste cannot be taken lightly, it needs the cooperation of all government

officials from the head of environment office. villages and sub-districts, KB cadres, PKK mobilization teams, and other parties concerned so that this problem can be resolved. The community is unruly, especially those who rent a house on a monthly basis, They do not care about the cleanliness of the environment of the house and its surroundings. Binding on the payment of waste contributions associated with security is a good idea. But it is always interpreted otherwise by those who have awareness, in terms of cheap dues around 15,000 rupiah. To buy a pack of cigarettes and coffee in the café they can afford. It is difficult for them unless they are aware of and care about the environment. In my experiece, I've been vigil at night, I always see garbage on the big street near the house strewn dumped by irresponsible people, a lot of it. There's something I caught my hand, I asked for his ID card and I tell you about the law of garbage and love the choice ya, I offer you to go to the police station or to clean the environment by removing the garbage he has already scattered in the street, yes use the threat of prison so. There was even a fight, which ended up getting emotional with each other so he was with my friend and accidentally hit him. It was a long affair, he ended up going to the police station, and I was also called to the police station as a witness, and the case just stopped. In my conclusion, there needs to be coordination and cooperation of everyone to care about household waste for the health of our environment".

Mrs. E, Village head of Asam Kumbang. Question: Participation of village and environmental government officials as well as public awareness about family waste.

She said: "Public awareness is lacking, although sanctions have also been strengthened. But the sanctons do not deter them and they still do not care. In my view, communication should be continued using different ways and approaches, not least those in the Kampung KB area and its surroundings. The community must respond to government policies to create a clean, healthy, and waste-free environment. Efforts are still made through mutual help to clean their homes and residential environments instructed through their respective ward heads. We are moving together (inherent participation) with government officials from the environmental and village levels, PKK mobilization teams, KB cadres, MFID, Babinsa, and community leaders to raise this important garbage issue. Moreover, the rainfall is high lately, and briefly, it has been flooding. Without awareness and cooperation, it is difficult to build a clean and healthy environment".

FGD results show that in general, the models of communication used by communicators come in the form of face-toface communication, group communication and new media communication through social media, such as WhatsApp (private networks and groups) to invite the public to mutual assistance activities. This proves that implementers consisting of government 
officials, ranging from the head of the environment, $\mathrm{KB}$ cadres and PKK mobilization team, community leaders to village heads and head of village secretaries, have performed their duties well in making the community in the village and outside the $\mathrm{KB}$ village aware of household waste management.

In addition, people in the Kampung KB area are not only aware of long-term contraceptive programs (PKJP), reproductive health, and the like, but also more about the resilience of family functions, one of which is environmental development. A healthy environment, with a simple movement to care for waste such as household waste, is worthy of appreciation that needs to be continuously socialized. Although it is realized that the community still does not care about household waste. This is reinforced by the observations of researchers in both locations, where piles of garbage are everywhere and left alone. Although there are motorcycle facilities or rickshaws transporting garbage, awareness to pay for the distribution of garbage is not heeded and also the garbage is not disposed of directly to the landfill. This becomes an obstacle for village and sub-district government officials to discipline the residents. As said by the Head of Asam Kumbang Village, The Head of Environment to researchers, that they have difficulties making the public aware of household waste, especially those who rent a house. Thus, the communication campaigns process is one-way from the government to the community.

Communication campaigns have been conducted continuously through various methods of communication such as persuasive communication by face-to-face or group communication at the time of mutual assistance, services in Posyandu, studying or at the wedding venue or circumcision delivered about household waste should be considered because it will cause clogged trenches, unhealthy and uncomfortable environment due to among others the occurrence of garbage scattered and not discarded. But it seems that the awareness of the community has not been maximized in addressing household waste. This is also inseparable from the observation of researchers in both locations, where household waste is not in place scattered, no trash cans are found and residents do not want to participate in garbage dues and let someone quote household waste. Moreover, the movement to separate organic and non-organic waste is still the home task of government officials from both the head of the environment, the PKK mobilization team, and the Family Planning Extension to the Village and Sub-District levels. Although environmentalists, village officials, and district have been trying to make the community aware of household waste, there is still no optimal result in its completion in the field.

The Communication Campaign process on waste from the description above runs one way from government officials and then through media channels or interpersonal channels with the same message and is done repeatedly so that the public understands and wants to carry out what is directed by communicators. If described the process that takes place as below.

Feedback

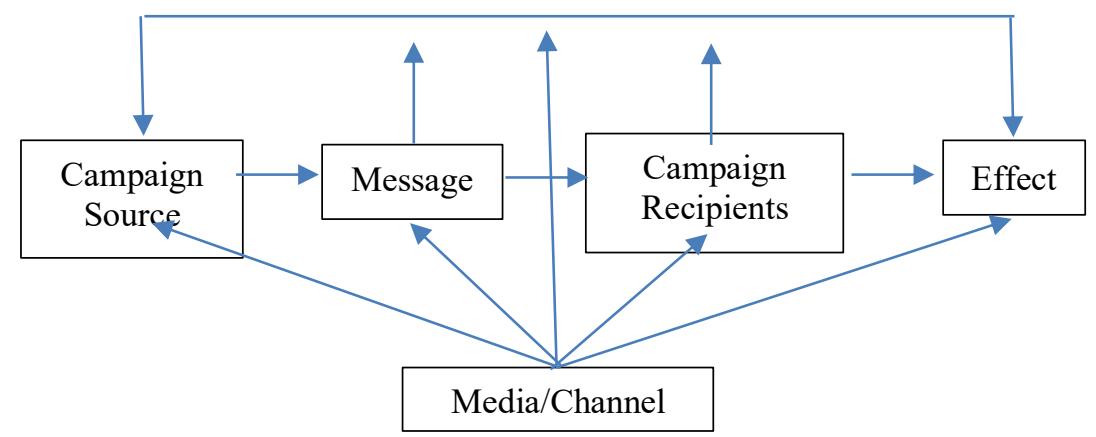

Figure 2. Communication Process

This communication campaign can be easily identified using a transmission approach rather than an interaction approach. This can be seen from the role of the village and village officials, KB cadres, PKK mobilization teams, and community leaders in campaigning for the movement of family waste, both through personal channels/face-to-face communication, 
group communication and mass communication as well as new media communications such as social media whatsApp and Facebook.

\section{Conclusions}

The communication process takes place face-to-face and group communication from the village government officials to the community in $\mathrm{KB}$ village. Communication is done persuasively in the hope of increasing public awareness to care about household waste. The efforts that have been made by the Village and Sub-District Government Officials to make the community aware of their duties to care for household waste produced by the family through direct action and routine activities (continuously) through mutual assistance at least once a week with the motto 'Clean Saturday' so that the community will finish the environment of their home. The communication campaign model is a transmission model where the source (campaigner) actively seeks to influence the recipient (campaigner) who is in a passive position. This model is in line with the process of exchanging messages during the one-way campaign, namely from source to recipient where the source actively constructs the message to create a change in behavior in the recipient (audience).

\section{Acknowledgments}

The researchers thanked Prof. Herman Munir, M.Sc and Mrs. Dr. Dra. Ir. Chairani Hanum, M.S as chairman and secretary of USU research institute that has provided and funded Talenta 2020 and also to Mr. Drs. Hendra Harahap, M.Si, Ph.D as vice dean 3rd of FISIP USU for his attention and cooperation.

\section{References}

Ananda, P. (2018). The Unexpected Dangers of Long-Term Plastic Waste. OkezoneTv. Retrieved from https:/lifestyle.okezone.com/read/2018/06 /05/481/1906793/danger-long-termplastic waste that you didn't expect.

Astuti, F., A., Asrifah, D., Wiriadri, I., K., Utami A., Santoso, D., H. (2018). Identification of the Perception of Waste Treatment Patterns by the Community in Increasing the Effectiveness of Waste Management in Yogyakarta City. Journal of Science Tech. 4(2).
Bungin, B. (2015). Qualitative Research Methodology. Jakarta: Rajawali Press.

Badan Pusat Statistik Kabupaten Deli Serdang (2020). Population Data and Statictic for Deli Serdang and Medan City 2017-2018. Retrieved

from: https://deliserdangkab.bps.go.id/ accessed (23/2/2020).

Cox, R. (2010). Environmental Communication and the Public Sphere. Sage Publication.

Ekasari, A. (2018). Drive for Environmental Responsibility, Collectivism and Subjective Norms in Behavioral Intention user Reusable Bag. Journal of Management and Marketing Services. 11(2).

Fatia, D., and Sugandi, Y., S. (2019). Movement Without a Straw: Avoid Damage to the Environment. Socioglobal Journal: Journal of Sociological Thought and Research. 3(2).

Flor, A., G. (2004). Environmental Communication: Principles, Approaches and Strategies of Communication, Applied to Environmental Management. Philipines, University of the Philippines.

GatraCom (2019). Produksi Sampah di Sumut Mencapai 3,7 Juta Ton Pertahun. Retrieved from: https://www.gatra.com/detail/news/42256 6/Economy/production-sampah-di-sumutmencapai-37-juta-ton-pertahun (accessed 11/1/2020).

Intan, G. (2018). Save the Environment, Movement Without Plastic Straws Starts Trending in Society. VOA Indonesia. Retrieved From: https://www.voaindonesia.com/a/selimpa n-lingkungan- movement-tanpasedotanmulai-nge-trend-dimasyarakat/4664637.html published on 9 November.

Juniman, P, T. (2018). Movement Without a Straw, a New Way to Reduce Plastic Straws. CNN News Indonesia. Retrieved From:

https://www.cnnindonesia.com/gayahidup /20180629142643-282-310154/ Gerakantanpa-sedotan-cara-baru-kurangisampahplastik published on 2 July.

Kriyantono, R. (2010). Practical Communication Research Techniques. Jakarta: Kencana Prenada Media Group.

Lubis, L., A., and Wijaya, H. (2017). Family Planning Communication Strategy On 
Field Officer Used For Daily Planning Program In Langkat District, Sumatra, Indonesia. IJSTR, 6(6).

Lubis, L., A. (2018). Practical Understanding of Intercultural Communication. Medan: USU Press.

Lubis, L., A., \& Pohan, S. (2018a). The Communication Competence of Family Planning Field Officers in Using the Family Planning Program Socialization Method in Batang Angkola District, South Tapanuli Regency. Banjarmasin: E-Book 1 ASPIKOM Lambung Mangkurat University.

Lupis, L., A., \& Pohan, S. (2019). Preparation Communication Competence of Field Officer of Family Planning in Socialization of Family Planning Program in Batang Angkola Sub-District, South Tapanuli. IJSTR, 8(1).
Marliani, N. (2014). Utilization of Household Waste (Inorganic Waste) As A Form Of Implementation of Environmental Education. Formative Journal. 4(2).

Miles, M., B., and Huberman A., M. (2009). Qualitative Data Analysis. Jakarta: UI Press.

Mulyana, D. (2018). Qualitative Research Methodology: A New Paradigm of Communication and Other Social Sciences. Bandung, PT Remaja Rosdakarya.

Walgito, B. (2000). Guidance and Counseling (Study and career). Yogyakarta: Andi Offset.

Wirdhana, I., et al. (2013). Effective Communication Between Parents and Adolescents. Jakarta: BKKBN. 